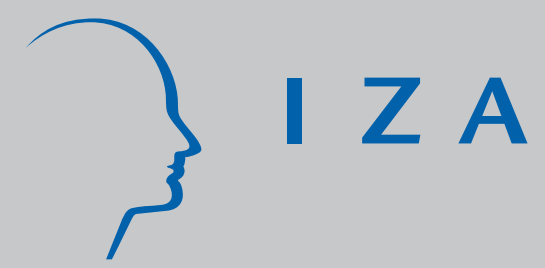

IZA DP No. 9420

Do E-Verify Mandates Improve Labor Market Outcomes of Low-Skilled Native and Legal Immigrant Workers?

Sarah Bohn

Magnus Lofstrom

Steven Raphael

October 2015 


\title{
Do E-Verify Mandates Improve Labor Market Outcomes of Low-Skilled Native and Legal Immigrant Workers?
}

\author{
Sarah Bohn \\ Public Policy Institute of California \\ Magnus Lofstrom \\ Public Policy Institute of California and IZA \\ Steven Raphael \\ University of California, Berkeley and IZA \\ Discussion Paper No. 9420 \\ October 2015 \\ IZA \\ P.O. Box 7240 \\ 53072 Bonn \\ Germany \\ Phone: +49-228-3894-0 \\ Fax: +49-228-3894-180 \\ E-mail: iza@iza.org
}

Any opinions expressed here are those of the author(s) and not those of IZA. Research published in this series may include views on policy, but the institute itself takes no institutional policy positions. The IZA research network is committed to the IZA Guiding Principles of Research Integrity.

The Institute for the Study of Labor (IZA) in Bonn is a local and virtual international research center and a place of communication between science, politics and business. IZA is an independent nonprofit organization supported by Deutsche Post Foundation. The center is associated with the University of Bonn and offers a stimulating research environment through its international network, workshops and conferences, data service, project support, research visits and doctoral program. IZA engages in (i) original and internationally competitive research in all fields of labor economics, (ii) development of policy concepts, and (iii) dissemination of research results and concepts to the interested public.

IZA Discussion Papers often represent preliminary work and are circulated to encourage discussion. Citation of such a paper should account for its provisional character. A revised version may be available directly from the author. 


\section{ABSTRACT \\ Do E-Verify Mandates Improve Labor Market Outcomes of Low-Skilled Native and Legal Immigrant Workers?}

We examine the impact of state level legislation against the hiring of unauthorized immigrants on employment opportunities among competing low-skilled workers. Our focus is on the role of E-Verify mandates and specifically, we test for effects of the 2007 Legal Arizona Workers Act (LAWA) on employment outcomes of low-skilled native-born and legal immigrant workers in Arizona. We use the synthetic control method developed by Abadie, Diamond and Hainmueller (2010) to select a group of states against which the labor market trends of Arizona can be compared. Our results suggest that contrary to its intent, the Legal Arizona Workers Act does not appear to have improved labor market outcomes of competing legal low-skilled workers. In fact, we find some evidence of diminished employment and increased unemployment among legal low-skilled workers in Arizona. These findings are concentrated on the largest demographic group of workers - non-Hispanic white men. While they are less likely to find employment, those who do have on average higher earnings as a result of LAWA. The pattern of results points to both labor supply and labor demand contractions due to LAWA, with labor supply dominating in terms of magnitude.

JEL Classification: J8, J15, J18, J21, J31, J61

Keywords: $\quad$ illegal, unauthorized, undocumented, immigration, E-Verify, Arizona

Corresponding author:

Magnus Lofstrom

Public Policy Institute of California

500 Washington Street, Suite 600

San Francisco, CA 94111

USA

E-mail: Lofstrom@ppic.org 


\section{Introduction}

During much of the 2000s, lawmakers in the U.S. Congress have considered changes to the country’s immigration policy though comprehensive immigration reform. To date, all efforts to pass a major reform have met defeat. A key reason behind the Congressional gridlock on immigration is the controversial issue of how to address the country's unauthorized immigrant population, which has grown from about 3 million in the late 1980s to around 11.7 million in 2012 (Passel, Cohn and Gonzalez-Barrera, 2013). Although the concerns regarding unauthorized immigrants cover a broad range of issues, one frequently cited apprehension is that the presence of such a large number of unauthorized workers negatively affects labor market outcomes of legal workers.

In this paper, we take advantage of legislation in Arizona against the hiring of unauthorized immigrants to assess whether these changes had any impacts on the employment opportunities of low-skilled U.S. born and legal immigrant workers. Our previous research finds that this policy - the 2007 Legal Arizona Workers Act - significantly and quickly decreased the state’s unauthorized immigrant population and limited their employment opportunities, especially in formal wage and salary work (Bohn, Lofstrom and Raphael (2014) and Bohn and Lofstrom (2013)). The Legal Arizona Workers Act (LAWA) is the first of now numerous state policies to require employers to use of E-Verify, a federal electronic system, to check the work authorization of new hires and to set forth sanctions for employers who do not.

LAWA and similar policies in other states respond to the fact that employment is the primary draw for most unauthorized immigrants. Arizona is a state leading the charge against illegal immigration, highlighted by the publicized and controversial Senate Bill 1070 in April 
2010. ${ }^{1}$ But Arizona had been making ground-breaking policy targeting unauthorized immigrants years before; the Legal Arizona Worker Act (LAWA) was passed in July 2007 and implemented in January 2008. The law imposed strict employer sanctions against firms knowingly hiring unauthorized workers - business licenses suspension and possible revocation for repeat offenders. The arguably most important feature of LAWA is the requirement that all employers use E-Verify for all new hires. Since LAWA was enacted in 2008 (and upheld in May 2011 by the U.S. Supreme Court) many other states have followed suit. ${ }^{2}$ Six states have since implemented similar mandates (Utah, South Carolina, Mississippi, Georgia, North Carolina, and Oklahoma) and other states - as well as the federal government - have implemented E-Verify requirements for public contractors. Arizona provides arguably the best natural experiment for understanding the impacts of state legislation on employment of unauthorized immigrants, being the first mover and having implemented a broad E-Verify mandate, with strong employer sanctions attached.

Very little is known about the impacts of these laws, but our previous research shows that LAWA induced sizeable responses among the unauthorized population. Bohn, Lofstrom and Raphael (2014) finds that the population of non-citizen Hispanic immigrants in Arizona - a high proportion of whom are unauthorized immigrants -fell by more than 90,000 due to LAWA. Bohn and Lofstrom (2013) extends the work to assess whether the policy affected labor market outcomes of unauthorized immigrants. We find evidence of a substantial decrease in the rate of

\footnotetext{
${ }^{1}$ SB 1070 targets unauthorized immigrants directly, as opposed to employers, and criminalizes failure to carry immigration documents and give the police broad power to detain anyone suspected of being in the country illegally. The constitutionality of the law is in question and prior to enactment a federal judge issued an injunction blocking the most controversial provisions, including the one requiring police to check individual's immigration status while enforcing other laws if there was reason to believe the person was in the country illegally.

${ }^{2}$ Although the legislation has faced a number of legal challenges, it has been upheld by the federal district and appellate courts. The challenges to LAWA focus on the right of states to legislate on immigration enforcement. The U.S. Supreme Court heard arguments in the case, Chamber of Commerce et al v Whiting, in December 2010 and ruled in favor of the legislation in May 2011. The clearing of the constitutionality hurdle may spur additional interest in passing such laws.
} 
formal employment by about 11 percentage points among likely unauthorized immigrants, defined as Hispanic non-naturalized low-skilled men, as well as a doubling of the selfemployment rate. The timing of these changes coincides with LAWA and the changes are not found in comparison states. With these substantial impacts on the unauthorized population, the policy change in Arizona appears to be an excellent opportunity to assess whether competing authorized low-skilled workers benefitted from the legislation.

A few papers have assessed the impact of E-Verify on the labor market outcomes of legal workers in a context broader than Arizona. Good (2013) estimates sizeable negative employment effects among competing authorized workers as a result of omnibus state policies, which include E-Verify mandates and other state actions. Amuedo-Dorantes and Bansak (2012, 2013) provide some of the first evidence on the impact of E-Verify on employment and wages among native-born non-Hispanics, a relatively broad group. Nationwide, in states that passed E-

verify laws (of varying degree), native-born non-Hispanic men are more likely to be employed (2 percentage points) and at higher wages (nearly 3 percent) than similar men in other states. We add to this literature by explicitly addressing the endogeneity of E-Verify passage and creating robust counterfactual, especially crucial for assessing employment impacts in a recessionary period.

\section{E-Verify as a State-level Enforcement Tool}

The failure of federal reform has spurred an unprecedented level of state legislative activity in immigration policy in recent years. The new state laws related to employment of unauthorized immigrants vary greatly in terms of restrictiveness and implementation. Most of the 
comprehensive laws include mandated use of E-Verify to varying degree. Arizona's LAWA was the first comprehensive mandate issued and remains arguably the most restrictive.

\section{E-Verify}

E-Verify is a voluntary online system created and managed by the federal government to provide information to employers about whether an individual is authorized to work in the United States. E-Verify checks workers' Form I-9 information for authenticity and work authorization status against Social Security Administration (SSA) and Citizenship and Immigration Services (USCIS) databases. The system applies to all workers, citizens and noncitizens alike, and employers are not permitted to use E-Verify until a new hire has been made.

E-Verify provides fast results, if identity and work authorization are confirmed—which, according to Westat (2009), occurs about 95 percent of the time. When confirmation is not granted ("tentative non confirmation” or TNC), the employee may appeal. While a TNC is being contested by a new hire, employers are not allowed to dismiss the worker solely on the basis of the record. If an employee fails to or is unable to correct a TNC within two weeks, employers must terminate the employee. Cited problems with E-Verify include delays in correcting tentative non-confirmations, erroneous confirmations, and insufficient capacity as more employers enroll. Intensive refinement of the system in recent years has led to improvements, especially in error rates. ${ }^{3}$ The costs - primarily time and energy - of correcting errors fall on the new hires as well as on local DHS and SSA offices where individuals must go to correct errors. Verification can be circumvented if employers avoid use or if applicants submit false documents.

\footnotetext{
${ }^{3}$ For authorized workers, the accuracy rate of E-Verify is at least 99 percent, but for unauthorized workers the error rate may be as much as 54 percent (Westat 2009).
} 
A photo identification tool was added to E-Verify in 2009 to address this latter concern, though most E-Verify polices include penalties for identity theft as well.

The results of E-Verify at this time are not reported to any agency responsible for immigration enforcement. That is, even if a new hire is found to be unauthorized, these results are not transmitted to DHS or ICE for investigation, detainment, or deportation of the individual. Thus, enforcing use of E-Verify must come from an external source.

The 2007 Legal Arizona Workers Act

The Legal Arizona Workers Act (LAWA) was signed into law in July 2007 and enacted on January 1, 2008. LAWA mandates the use of E-Verify by all employers in Arizona to ensure the legal authorization to work for all new hires. The law also imposes sanctions on employers who "knowingly" hire unauthorized immigrants: a business license suspension for the first offense and license revocation upon a second. LAWA is unique among subsequent state EVerify mandates in that it covers all firms, not just public agencies or those with state government contracts. It also mandates that employers of all sizes use E-Verify as of the implementation date. Many states that have since implemented E-Verify often phase in employers by business size and/or include exemptions. LAWA does include an exemption we find to be highly relevant: independent contractors are not subject to the mandate. Its broad range makes LAWA a good example of state legislation that mimics recent federal reform proposals. Importantly, Arizona is also one of a few places where all employers have been required to use E-Verify for a sufficient period of time to allow for a reliable empirical evaluation.

We expect that LAWA's impacts to-date largely stem from a deterrent or compliance effect prompted by the E-Verify mandate rather than from employer sanctioning. To date few 
employer sanctions have been assessed. Through April 2010, more than two full years following LAWA's enactment, only three prosecutions had been pursued, and all in a single county (Maricopa). Few sanctions may reflect the lack of resources in the County Attorney offices responsible for investigating claims. Or, few sanctions may reflect high compliance among employers. Statistics from the E-Verify system indicate growth in number of firms enrolled: from 300 in March 2007 in Arizona, to 38,000 in January 2010 (Westat (2009), Arizona Attorney General's Office (2010)). At that time, Arizona firm enrollment represented roughly one-third of all firms enrolled nationwide. Further, estimates suggest that roughly 700,000 new hires made between October 2008 and September 2009 were run through E-Verify in Arizona (Arizona Republic (2010)). This correlates to roughly 50\% of all new hires in the state, a high degree of compliance given that unauthorized immigrants comprise only $10 \%$ of Arizona's labor force (estimate from Passel and Cohn (2009)).

\section{Theoretical Predictions of the Labor Market Impacts of E-Verify Mandates}

The intention of E-Verify mandates in general and LAWA specifically is to reduce the unauthorized immigrant population by deterring the hiring of unauthorized workers. Legislation such as LAWA can potentially achieve this goal by affecting both the supply and demand side of the labor market. The extent to which these labor market effects change the employment opportunities of competing authorized workers also depends on their substitutability with targeted unauthorized immigrants.

On the supply side, the E-Verify requirement makes it more difficult for unauthorized immigrants to find work in Arizona, making the state less desirable for unauthorized workers and ostensibly increasing employment opportunities of competing legal workers. Our previous work 
finds strong evidence of a labor supply effect among unauthorized; the law induced a noticeable decline in the unauthorized population and a decline in employment among unauthorized workers who continued to reside in Arizona. Employment declines were attenuated by a shift from salary work to self-employment among the targeted immigrants, likely driven by LAWA's exemption for independent contractors. These results are consistent with - but not limited to - a decline in labor supply. All else equal, a labor supply contraction should increase wages for workers who remain in the market. It will also yield an overall decline in employment. The magnitude of these wage and employment effects would theoretically vary depending on the elasticity of labor demand and supply (which may also vary across authorized and unauthorized worker subgroups).

However, LAWA may also impact labor demand in a number of ways, making these predicted impacts on authorized workers less determinate. The E-Verify mandate increases the cost of hiring generally speaking, potentially driving down labor demand. ${ }^{4}$ This shift would predict additional downward pressure on employment but the resulting wage rate is ambiguous. In addition, labor demand channels may impact unauthorized and authorized workers differentially. If employers can distinguish between unauthorized and authorized workers, employer sanctions increase the cost to employers of hiring unauthorized immigrants specifically, thus reducing employers' desire to hire them and increasing their demand for legal workers. Standard labor theory predicts that this would induce reinforcing downward effects on employment opportunities for unauthorized immigrants but offsetting effects on other workers, with wage effects again indeterminate.

\footnotetext{
${ }^{4}$ Various Chambers of Commerce have often opposed E-Verify mandates, bringing a case all the way to the U.S. Supreme Court, suggesting the mandate imposes significant costs on employers.
} 
Whether these standard effects occur depends in large part on the degree to which authorized and unauthorized workers compete with one another in the labor market. But the substitutability of authorized workers for unauthorized is limited by differences in skills of workers and their availability. Overall, this suggests that the labor market effects of LAWA are likely to vary by skill, nativity, ethnicity, gender, and the interaction of these dimensions and that, if there are benefits to be had, those authorized workers most likely to benefit are those most closely substitutable for unauthorized workers.

An additional complication arises when employers cannot easily distinguish the documented from the unauthorized. Specifically, if employers cannot tell with certainty who is and who is not authorized, employers may infer legal status through such visible signals as ethnicity, accent, or surname. This likelihood is heightened by details of the E-Verify mandate; employers use the system after a hiring decision is made and cannot terminate a worker whose status is not confirmed, pending a two-week period in which the worker can contest the database's personal information. This element adds uncertainty and increases the expected hiring cost, and if relevant, possible training cost. Employers wishing to avoid the risk of hiring undocumented workers may reduce their hiring of Latino applicants in particular and increase their hiring of applicants who are deemed lower risk for whatever reason. Concern that sanctions targeting the hiring of unauthorized immigrants would result in employment discrimination against Hispanics is not new. In fact, this was a key point of contention in the legislative debate surrounding the 1986 Immigration Reform and Control Act (IRCA) and research finds that in the immediate aftermath of IRCA's passage, the hourly earnings of Latinos did decline (Bansak and Raphael 2001). ${ }^{5}$

\footnotetext{
${ }^{5}$ IRCA created the legal obligation for employers to verify the identity and work eligibility of all applicants, and introduced a series of graduated sanctions for employers who failed to comply with the verification, record
} 
It is clear that there are many standard labor supply and demand channels through which LAWA may impact authorized workers. Since it is impossible to theoretically predict the net effects of the channels discussed here, analyzing the impacts of these laws on native and legal immigrants requires an empirical analysis.

\section{Data and Empirical Strategy}

To assess the labor market effects of LAWA on authorized workers, we analyze data from the Current Population Survey (CPS) collected between 1998 and 2010. These data provide details on the employment, work, and earnings of individuals in each state as well as information on race/ethnicity, education, age, and other demographic characteristics including immigration status (native-US born or foreign- born naturalized citizen, or not a citizen).

\section{Defining Groups of Interest}

The CPS data do not allow for direct identification of work authorization status. However, we estimate that in Arizona upwards of 80 to 90 percent of noncitizen men of working age and of Hispanic origin with relatively low levels of education (high school or less) are likely to be unauthorized (Bohn, Lofstrom and Raphael (2014) based on Passel and Cohn (2009a)). ${ }^{6}$ For the present analysis of competing workers, then, we utilize the same age, education, and origin

keeping, and hiring provisions of the law. Opponents of the legislation expressed concern that these provisions would lead to discrimination against all Hispanics.

${ }^{6}$ For example, our calculations from Census data indicate roughly 517,000 non-citizen Hispanic immigrants resided in Arizona in 2008. For this same year, Passel and Cohn (2009) estimate that there were 475,000 unauthorized immigrants in the state. Similarly, for our finer definition of likely unauthorized workers used in the traditional difference-in-difference approach, based on ACS data, we estimate 229,000 likely unauthorized in Arizona in 2008 whereas Passel and Cohn (2009) estimate 240,000 unauthorized immigrants in Arizona's labor force in the same year. 
criterion but identify likely authorized workers as those who report being naturalized or nativeborn. Our target group defined in this manner may exclude some authorized workers because self-reported citizenship status is likely to be reported with some error, and because citizenship status differs from work authorization status in some cases (for example, some noncitizen men may be authorized to work via nonimmigrant visa programs). However, our conservative definition of low skilled authorized Hispanic workers should yield a group most likely to be authorized to work.

As described above, LAWA's effects might vary to the degree employers can substitute similar workers and distinguish unauthorized from authorized workers. For that reason, we examine three groups defined by race-ethnicity and citizenship status with plausibly varying degrees of similarity with unauthorized immigrants (from most to least similar): (1) Foreign-born naturalized citizen Hispanics, (2) Native-born Hispanics, and (3) Native-born non-Hispanic whites. Among all groups, we restrict analysis to working age men (16-60) with high school education or less. While other racial-ethnic group outcomes are of interest (in particular, nativeborn non-Hispanic blacks), the small population of minority groups beyond those of Hispanic origin in Arizona preclude robust analysis. The native-born, less-skilled male workforce in Arizona is comprised primarily of white men (roughly 60 percent), followed by Hispanic men (30 percent). To the extent that authorized workers defined here are not perfect substitutes for unauthorized workers in Arizona - or do not fully capture the true substitute workers - our estimates may attenuate LAWA's true effect. 


\section{The Data}

The CPS provides a wealth of information on labor market outcomes and at high frequency (monthly). We pool monthly data within year in order to obtain sufficient sample size for analysis on the narrowly defined population groups necessitated by this study. The average sample size within the population groups of interest is given in the first row of Table 1 . We restrict our sample period to 1998-2009. Additional years of data are available; however, harsh immigration policies (namely the controversial SB 1070) were passed in Arizona after 2009, potentially biasing estimates of LAWA's impact beyond 2009. Larger samples are available in the American Community Survey, but do not provide the long time series and high frequency data necessitated by our empirical approach, discussed below. We estimate impacts on a number of outcomes at the state-population group level: employment, unemployment, and labor force participation and earnings measured annually, weekly, and hourly. ${ }^{7}$ Table 1 presents the average values of these outcome variables for the three population groups of interest, in both Arizona and the potential comparison states.

\section{Use of a Synthetic Control}

In order to identify the causal impact of LAWA on employment outcomes in Arizona, we employ the synthetic control approach of Abadie, Diamond and Hainmueller (2010). Key to the identification strategy is charting the appropriate counterfactual path for Arizona in the absence of LAWA. There are a number of approaches one could employ. One is to select states that share similar population and economic characteristics and trends as Arizona; for example, the

\footnotetext{
${ }^{7}$ When pooling monthly CPS data, some individual observations are repeated due to CPS sampling procedures and raising concern about the standard error on parameters of interest. Our empirical methods minimize such concern by relying only on state-population group averages (rather than individual outcomes) for all variables of interest and by utilizing nonparametric procedures to obtain inference.
} 
states bordering Arizona (a traditional difference-in-difference approach). Another would be to employ a data-driven search for comparison states based on pre-LAWA population and employment characteristics and trends (the synthetic control method of Abadie et al (2010)). We focus on the latter because it is arguably the most reliable and essentially incorporates the first strategy. It allows the data to tell us which states best match Arizona's pre-LAWA experience.

The synthetic control method allows for robust analysis in the single policy change single state context. We summarize the methodology for charting a counterfactual post-LAWA path for Arizona here. The basic idea is to generate a comparison group from a convex combination of states in a large donor pool. Let the index $\mathrm{j}=(0,1, \ldots, \mathrm{J})$ denote states. The value $\mathrm{j}=0$ corresponds to Arizona and $\mathrm{j}=(1, \ldots, \mathrm{J})$ correspond to each of the other $\mathrm{J}$ states that are candidate contributors to the control group (or in the language of Abadie et. al, the donor pool). Define $F_{0}$ as a $9 x 1$ vector with elements equal to the group-specific employment outcome in Arizona in years 1998 through 2006 (the nine years we use throughout this paper as our preintervention period). Similarly, define the $9 \mathrm{xJ}$ matrix $F_{1}$ as the collection of comparable time series for each of the J states in the donor pool (with each column corresponding to a separate state-level time series for the period 1998 through 2006).

The synthetic control method identifies a convex combination of the $\mathrm{J}$ states in the donor pool that best approximates the pre-intervention time series for the treated state. Define the Jx1 weighting vector $W=\left(w_{1}, w_{2}, \ldots, w_{J}\right)^{\prime}$ such that $\sum_{j=1}^{J} w_{j}=1$, and $w_{j} \geq 0$ for $\mathrm{j}=(1, \ldots, \mathrm{J})$. The product $F_{1} W$ then gives a weighted average of the pre-intervention time series for all states omitting Arizona, with the difference between Arizona and this average given by $F_{0}-F_{1} W$. The synthetic control method essentially chooses a value for the weighting vector, $W$, that yields a synthetic 
comparison group (consisting of an average of some subset of donor states) that best

approximates the pre-intervention path for Arizona. Specifically, the weighting vector is chosen by solving the constrained quadratic minimization problem

$$
\begin{aligned}
& W^{*}=\underset{W}{\arg \min }\left(F_{0}-F_{1} W\right)^{\prime} V\left(F_{0}-F_{1} W\right) \\
& \text { s.t. } \\
& W^{\prime} i=1, w_{j} \geq 0, j=(1, \ldots J)
\end{aligned}
$$

where $V$ is a 9x9, diagonal positive-definite matrix with diagonal elements providing the relative weights for the contribution of the square of the elements in the vector $F_{0}-F_{1} W$ to the objective function being minimized.

Once an optimal weighting vector $W^{*}$ is chosen, both the pre-intervention path as well as the post-intervention values for the dependent variable in "synthetic Arizona" can be tabulated by calculating the corresponding weighted average for each year using the donor states with positive weights. The post-intervention values for the synthetic control group serve as our counterfactual outcomes for Arizona.

\section{Empirical Methodology}

Our principal estimate of the impacts of LAWA on labor market outcomes uses the synthetic control group to calculate a simple difference-in-differences estimate. Specifically, define Outcome $_{\text {pre }}^{A Z}$ as the average value of the outcome of interest for Arizona for the pre-intervention period 1998 through 2006 and Outcome $e_{\text {post }}^{A Z}$ as the corresponding average for the two posttreatment years 2008 and 2009. Define the similar averages Outcome $e_{\text {pre }}^{\text {synt }}$ and Outcome ${ }_{\text {post }}^{\text {synt }}$ for the synthetic control group. Our difference-in-differences estimate subtracts the pre-intervention 
difference between the averages for Arizona and synthetic Arizona from the comparable postintervention difference, or

$$
D D_{A Z}=\left(\text { Outcome }_{\text {post }}^{A Z}-\text { Outcome }_{\text {post }}^{\text {syth }}\right)-\left(\text { Outcome }_{\text {pre }}^{A Z}-\text { Outcome }_{\text {pre }}^{\text {synth }}\right)
$$

To formally test the significance of any observed relative decline in Arizona's foreign-born population, we apply the permutation test suggested by Abadie et. al. (2010) to the difference-indifference estimator $D D .^{8}$ Specifically, for each state in the donor pool, we identify synthetic comparison groups based on the solution to the quadratic minimization problem in equation (1). We then estimate the difference-in-difference in (2) for each state as if these states had passed the equivalent of a LAWA with comparable timing. The distribution of these "placebo" difference-in-difference estimates then provides the equivalent of a sampling distribution for the estimate $D D_{A Z}$. To be specific, if the cumulative density function of the complete set of $D D$ estimates is given by $F($.$) , the p-value from a one-tailed test of the hypothesis that D D_{A Z}<0$ is given by $F\left(D D_{A Z}\right)$.

To interpret $D D_{A Z}$ as a causal estimate of LAWA's effects, we must make the case that LAWA represents an exogenous shock to the labor market and is not coincident with other factors that could affect employment of authorized workers. Though there are many factors that affect employment outcomes, threats to causality within the synthetic control framework are only relevant if they correspond precisely with regard to the timing of LAWA or the inability to generate a matching pre-LAWA trend from the donor pool. Factors such as differential population or industrial composition in Arizona and the donor states could plausibly make a pre-

\footnotetext{
${ }^{8}$ Buchmueller, DiNardo and Valletta (2009) use a similar permutation test to that described here to test for an impact of Hawaii's employer-mandate to provide health insurance benefits to employees on benefits coverage, health care costs, wages and employment.
} 
LAWA counterfactual difficult to construct, but we show below that for our outcomes of interest the synthetic control method passes reasonable tests of fit.

Threats related to the endogenous timing of LAWA are more difficult to address due to the timing of the Great Recession, which coincided with LAWA. A full examination is given in Bohn, Lofstrom, and Raphael (2014) and Bohn and Lofstrom (2013). In short, we argue that while LAWA was implemented at the beginning of the Great Recession, it was the result of a lengthy legislative process that began well before - that is, was exogenous to - the recession. Second, we find no evidence of coincident immigration enforcement either at the border or internal to Arizona that could have generated the same effects we identify via the synthetic control.

Nonetheless, the "Great Recession” occurred at approximately the same time of the enactment of LAWA, presenting a potentially confounding factor. Our empirical approach comparing trends in Arizona to other states accounts for any changes that affect the country as a whole (or the selected comparison states). However, one of the industries hit hardest, construction, is a leading employer of less-skilled workers. Furthermore, construction is one of the biggest industries in Arizona (representing close to 11 percent of total private employment in 2006). These facts, together, are related to the differential population composition of Arizona as well, which is of concern with regard to endogeneity of the policy. To validate our empirical approach, we assess official statistics on employment trends in Arizona and neighboring states during the recession.

The recent recession caused a clear reduction in Arizona's workforce. Figure 1 shows strong employment growth 2003-2006 with a noticeable slow down in 2007. This was followed by three and eight percent decreases in 2008 and 2009, respectively. Figure 1 also shows that the 
negative employment effects of the recession on employment were not any stronger in Arizona than in neighboring areas, including inland California (an area that shares many of the characteristics and trends of Arizona, is hence used in our empirical analysis). To test the data in Figure 1 further, we apply the synthetic control method to employment growth. This exercise confirms that there is no evidence that LAWA drives employment growth in Arizona.

Importantly, the recession was precipitated by a housing crisis, which brought new housing construction to a near standstill. The fact that many unauthorized immigrants and lessskilled workers generally are employed in the construction sector means that they may have been particularly affected by the recession. However, a look at construction employment data reveals no evidence that Arizona's construction industry fared much differently in the recession than its neighboring areas (Figure 2).

Overall, the data indicate that while Arizona's labor market was strongly affected by the recession, so were other states', including its neighbors. The similarity in trends indicates that our empirical strategy is appropriate for identifying differences across states since the recession appears to have affected all states similarly.

\section{Empirical Results - Did LAWA have labor market effects on authorized workers?}

LAWA induced a sizeable population reduction among unauthorized men in the Arizona labor markets (Bohn, Lofstrom and Raphael, 2014). Presuming that men born in the U.S. or naturalized citizens with similar education levels are substitutes, the labor supply shock alone should have decreased employment and increased wages in the market for low skilled workers. However, as detailed above, a number of demand-related adjustments due to LAWA are also plausible and complicate predictions of likely impacts. In this section we analyze employment 
rates and wage levels among authorized subgroups to better understand LAWA's impacts and likely mechanisms.

\section{LAWA Effects on Labor Market Status}

We begin our analysis of whether LAWA affected employment opportunities of low-skilled authorized workers in Arizona by examining employment rates (defined here as the ratio of persons employed). As discussed above, for those workers who remained in Arizona following LAWA, a variety of employment effects are plausible. To the extent that firms are hiring and are in compliance with LAWA, authorized workers who are close substitutes for unauthorized workers are more likely to find employment. However, three effects in the opposite direction may also be at play: scale effects due the increased cost of hiring, statistical discrimination against observably similar authorized workers, or complementarity between authorized and unauthorized workers. For these reasons, the impact of LAWA on employment among authorized workers is theoretically ambiguous.

The data indicates that all authorized low-skilled men in Arizona experienced a post-LAWA drop in employment. Figure 3 shows that both before and after the passage of LAWA in 2007, the employment rate of less-skilled naturalized Hispanic men was higher than that of nonHispanic native-born white men, which was in turn higher than that of Hispanic native-born men (averaging 85 and 72 percent and 64 percent over the entire period, respectively). The employment rate of native-born men fell more drastically - over 11 percentage points following LAWA than it did for the other groups (7 points for naturalized Hispanic immigrants and 6 points for native-born Hispanics). 
To probe the employment changes further, we apply the synthetic control approach and use the comparison states, which mimic Arizona’s 1998-2006 employment trend. In this exercise, we omit from the donor pool four states with broadly applied restrictions on the employment of unauthorized immigrants (Mississippi, Rhode Island, South Carolina, and Utah) even though the timing of their legislation post-dates LAWA. In identifying synthetic control states for placebo tests on each of the other states in the donor pool, we omit Arizona. Moreover, the donor pool of states is further restricted due to sample size limitations in the monthly CPS, and these limitations vary across the groups of workers we analyze. Generally the donor pool is most restricted for the group of naturalized Hispanic men and is broader for native-born non-Hispanic men. As stated previously, these sample size restrictions to some extent drive our focus on the largest group - native-born white men.

We assess whether the observed declines in employment among low-skilled authorized workers in Arizona following LAWA stand out from the counterfactual trend based on states in the donor pool. Figure 4 shows that prior to the passing of LAWA, the employment rate of native-born non-Hispanic white men in Arizona matched those of the same group in the synthetic control ("synthetic Arizona”) quite well. Pre-intervention differences between Arizona and the synthetic Arizona average near zero (0.0007). Hence, the synthetic control approach passes the first hurdle - succeeds in obtaining of convex combination of states that match Arizona's preLAWA trend. After 2007, however, we observe a divergent pattern. In the two post-LAWA years the employment rate for non-Hispanic white low-skilled men in Arizona is, on average, 4 percentage points lower than in the counterfactual.

Average differences between Arizona and synthetic Arizona are calculated in the pre-LAWA period (1998-2006) and post-LAWA period (2008-2009). These and the difference-in-difference 
estimate, $D D_{A Z}$, are presented in Table 2. Following LAWA, the employment rate of nonHispanic native-born white men with lower levels of educational attainment fell 4.4 percentage points relative to the synthetic control. To obtain a p-value on $D D_{A Z}$ as well its non-parametric rank, we replicate the synthetic control method on each state in the donor pool and obtain a distribution of difference-in-difference estimates.

Figure 5 graphically displays the raw data needed to conduct the permutation test of the significance of the relative declines in Arizona. Specifically, for each of the donor states as well as for Arizona, the figure displays the year-by-year difference between the outcome variable for the "treated" state and the outcome variable for its synthetic control. The differences for each of the donor states are displayed with the thin gray lines while the differences for Arizona are displayed by the black thick line. While the difference between Arizona and its synthetic control in the pre-LAWA period is well-inside the placebo distribution, in post-LAWA years the difference in Arizona begins to stand out.

The set of difference-in-difference point estimates estimated from this placebo distribution, $D D$, is used to calculate the p-value and rank of $D D_{A Z}$. These statistics are given in the last two columns of Table 2. We find that the difference-in-difference estimate for Arizona stands out as a clear outlier in the distribution of placebo estimates. The 4.4 point decline is the third largest decline among all forty-five states in the donor pool, and is statistically significant at the $7 \%$ level (the minimum p-value would be 0.022). ${ }^{9}$

\footnotetext{
${ }^{9}$ Note that not all states in the donor pool achieve a well-matched synthetic control in the placebo exercise. The District of Columbia is the observation for which the match is markedly off in 2007. Our results are not sensitive to the inclusion of the District of Columbia in the donor pool, and it is not one of the states assigned weight in the synthetic control. The states that do receive positive weight and contribute to the "synthetic Arizona" for employment rates among native-born white men are: Alaska (0.332), Illinois (0.054), Indiana (0.527), and Kentucky (0.087).
} 
Among the competing groups of Hispanic authorized workers, we find less convincing evidence of a decline in employment due to LAWA. The difference-in-difference estimates for both Hispanic native-born and naturalized men do not stand out among the placebo distribution of the synthetic control. The donor pool of states contributing to the distribution is smaller for each of these groups due to sample size, but are large enough that we would expect to detect significant impacts if they exist. If anything, the 4.5 point decline in employment among naturalized Hispanic immigrants is closer to significance and combined with the similar result for white native-born men suggests that authorized low-skilled workers may have faced a small decline in employment following LAWA. Using the size of the low-skilled working age nonHispanic white male population in Arizona in 2006 as the base (about 409,000), our estimates suggest that LAWA caused a drop in employment of roughly 18,000 such workers. If our estimated decline in employment among Hispanic naturalized immigrants is in fact valid but we fail to detect due to sample size limitations, the 4.5 point drop for this group would translate to roughly 9,800 workers.

Our previous work (Bohn and Lofstrom, 2013) documented a shift in employment from formal work (wage and salary jobs) to less formal (as measured by self-employment) among likely unauthorized men in Arizona due to LAWA. In the same study, we found no such evidence among competing low-skilled authorized workers - the same groups examined here. Thus, we next turn to additional outcome measures that may shed light on the effects of LAWA for authorized men.

The second and third panels of Table 2 present the impacts of LAWA on the unemployment rate and share of workers out of the labor force, among the three low-skilled authorized groups of men in Arizona. Overall, we fail to detect any strong statistical relationship between the 
passage of LAWA and unemployment or labor force participation. Among native-born lowskilled workers, unemployment rates jumped in Arizona relative to the synthetic control following LAWA on the order of 2 to 4 points. While towards the top range of estimates found in any state under the placebo test, the $D D_{A Z}$ estimates are significant at only the $20 \%$ level, outside the typically acceptable range. For white native-born in particular, we find a 1.8 point increase in the unemployment rate (shown graphically in Figure 6 and 7). The differential change in unemployment among naturalized Hispanics is close to zero.

LAWA-induced changes in labor force participation for these groups go in different directions and are similarly imprecise. Following LAWA, a higher share of white native-born and Hispanic naturalized low-skilled men reported non-participation in the labor market relative to the synthetic control (1.8 and 3.7 points, respectively). But a lower share of Hispanic nativeborn workers reported non-participation in the labor market, relatively speaking, post-LAWA. Again, however, the results are not statistically significant at levels that would lead us to make strong conclusions.

Note that all results presented in Table 2 are robust to alternative definition of the postLAWA period. While our main results assume the official post-LAWA years are the relevant period in which to examine impacts, we also test including 2007 in the treatment period. LAWA was passed in July of 2007 and implemented in January 2008, so including 2007 in the treatment period may catch some anticipatory effects but will also include a half-year before LAWA was passed. In general this alternative specification yields slightly attenuated results, consistent with the latter. For example, when 2007 is included in the post-LAWA period, the employment rate for white native-born men in Arizona falls 3.3 points relative to the synthetic Arizona (1 point 
less than our preferred specification). We conducted similar robustness checks for all results that follow, with similar conclusions. Full results are available upon request.

Combined with previous results, the pattern of findings suggests that LAWA had small, negative impacts on authorized workers, experienced as employment declines not likely to have been compensated by a shift to self-employment. ${ }^{10}$ Rather, we observe a disproportionate (though not strongly significant) increase in unemployment and non-participation in the labor force. The strongest findings suggest that employment effect effects were concentrated on lowskilled white workers, who experienced a small but statistically significant drop in employment and likely became unemployed or exited the labor force as a result. Considering the simultaneous outflow of unauthorized low-skilled immigrants from Arizona's labor force, these findings on slightly diminished employment opportunities among competing workers suggests that not only labor supply was constricted but employers likely reduced their demand to some extent as a result of LAWA. This scale effect may be interpreted as another unintended consequence of the policy.

\section{LAWA Effects on Earnings}

We next turn to earnings data to shed more light on plausible mechanisms driving employment declines observed for both authorized and - from previous work - unauthorized men in Arizona due to LAWA. If the employment decreases were entirely due to a decline in labor demand (for instance a pure scale effect due to increased cost of hiring), we would expect a corresponding decline in wages. If the employment declines were due entirely to a labor supply contraction, however, we would expect an increase in wages. In the previous section, our

\footnotetext{
${ }^{10}$ Regulations regarding business licensure vary by city and county. At the state level, the Arizona Department of Revenue does not require licensing of businesses that employ withholding-exempt employees only. This includes seasonal workers and domestic help. (Telephone communication with Arizona Department of Revenue 7/13/2010).
} 
estimates suggest that LAWA affected both labor supply and labor demand. Thus the effect on wages is determined by the relative size of these effects, and may increase (if labor supply dominates) or decrease (if labor demand dominates).

Assessing wage outcomes in the manner of this study is challenging. As discussed earlier, the synthetic control requires high frequency data over a long time period and our research question pertains to relatively small demographic groups. Questions on individual earnings are asked in the monthly CPS but only of a subsample too small within which to credibly identify our small population group of interest. Thus we turn to the March CPS sample (the “Annual Social and Economic Supplement”), where a larger number of respondents are asked about earnings over the previous year. And even though this is a quite large sample relative to other months of the survey, it is not sufficient to estimate robust earnings outcomes for enough states to conduct the synthetic control approach on any of our subgroups except nonHispanic White native-born low-skilled men. Fortunately - likely for similar reasons - this is the subgroup for which we estimated the most strongly significant and consistent results in terms of employment outcomes. Thus, we focus in this section exclusively on the earnings outcomes of non-Hispanic white native-born working age men with a high school education or less.

We utilize both reported earnings in a respondent’s current job (the “usual” earnings per week) and reported wage and salary earnings for the full year prior to the survey. In both cases we align the reference period for the earnings question with the pre- and post-LAWA analysis years. Thus we use different samples and different respondents to create the two sets of earnings outcome variables at the state level: 1999-2010 surveys for the "earnings last year" outcomes and 1998-2009 surveys for the "current earnings" outcomes. The "earnings last year" outcomes we calculate at the state-year level reflect earnings of state residents who did not move between 
surveys. Though we expect low-skilled white male migration rates to be quite low, as they typically are compared to other groups, a strong selectivity in the flow could bias our results but the direction is a priori unclear. A negatively selected outflow (for example those leaving because they earn low wages or are unemployed) may lead to an overestimate in the DD framework, whereas a positively selected outflow (for example high ability workers leaving for better opportunities) may lead to an understatement of LAWA's true effect.

Table 3 presents synthetic control estimates for a number of earnings-related outcomes for white low-skilled men in Arizona following LAWA. We find consistent evidence that earnings increased in Arizona following LAWA relative to comparison states. Average weekly earnings for low-skilled white men fell in 2008 and 2009 in both Arizona and the synthetic control states but declined relatively less in Arizona, by about $\$ 150$. Median earnings, not surprisingly, changed relatively less, about $\$ 116$ higher in Arizona relative to the synthetic control following LAWA. Both results are in the tails of the placebo distribution and are statistically significant beyond the 10 percent level.

Higher relative wages in Arizona following LAWA for low-skilled native-born white men are estimated regardless of which set of survey questions are utilized. Effects on average weekly earnings measured over the entire year are slightly smaller, possibly reflecting job loss, job change, or migration during the full year. On an annual basis, earnings in Arizona for this subgroup were $\$ 5500$ higher on average - and $\$ 1400$ higher at the median - following LAWA than in the synthetic control. All estimates are in the tails of the placebo distribution among donor pool states, but results pertaining to mean earnings are more strongly outliers. Also, hourly earnings are relatively higher by about $\$ 2$ in Arizona following LAWA (Figures 8 and 9). 
This last result on hourly wages affirms that it was not simply an adjustment in hours worked that generated earnings changes at the weekly or annual level.

The evident increase in wages for low-skilled native-born white men following LAWA, coupled with their falling employment rate, suggests that the constriction in labor supply of lowskilled workers overall dominated the reduction in labor demand for the same workers. LAWA appears to have improved the outcomes for low-skilled white men who were employed in the policy's aftermath, though fewer evidently found employment. Future research may shed light on additional mechanisms generating these outcomes, and the extent to which it is unique to Arizona in this time period. For example, there is a high degree of segregation in the sector of employment between low-skilled workers according to legal status. The extent to which an outflow of unauthorized workers may have induced legal workers to shift sectors in order to find employment and evidently higher relative wages (and the role the recession may have also played in doing so) plays a role in generating the effects we estimate here.

In addition, because data do not permit assessment of wages among competing groups of Hispanic workers, we are limited in the ability to draw strong conclusions about the likelihood employers engage in statistical discrimination as a result of LAWA. We find patterns of restricted employment opportunities (though imprecise) among Hispanic naturalized low-skilled men, perhaps the most likely to be impacted by statistical discrimination. Lacking better data on changes in earnings, however, it is impossible to discern whether or how much labor supply and demand shocks generated these patterns. 


\section{Conclusions}

Using the synthetic control approach for assessing the impact of a single policy change in single area, we estimate the impact of the Legal Arizona Workers Act of 2007 on labor market outcomes for legal workers in Arizona. Evidence to-date implies that LAWA was largely successful in meeting its goal of deterring unauthorized immigration to the state and preventing employment of unauthorized workers. In previous work, we estimated a roughly 17 percent decline in unauthorized population of the state and an 11 percentage point decline in formal employment both suggesting worsening labor market conditions for unauthorized due to LAWA. However, we also identified a shift towards informal employment, as measured by the 8 point increase in self-employment among unauthorized workers due to LAWA, hinting at one unintended consequence of the policy. In this paper we examine outcomes for workers likely to compete with - or substitute for - unauthorized immigrants. We find, in sum, no evidence that LAWA improved the likelihood of employment for low-skilled legal workers. In fact, we find some evidence of the opposite, which may be viewed as an additional unintended consequence of the policy.

Specifically, we find restricted employment opportunities - though much smaller than among unauthorized workers and non-existent for some demographic subgroups. We find the strongest pattern of evidence towards slightly lower employment levels but higher earnings among competing low-skilled white men. These findings suggest that, in addition to the constriction in labor supply of low-skilled men, LAWA also induced a labor demand downward adjustment, or scale effect.

In particular, we find that low-skilled native born white men in Arizona faced a lower employment rate on the order of 4 percentage points due to LAWA. Their unemployment rate 
increased by 2 points and the share who are out of the labor force increased as well, but these last two effects cannot be reliably attributed to LAWA. The earnings of this group, among those who were employed, increased as well - indicating the shock to labor supply among low-skilled workers overall was larger than the decrease in labor demand.

Although Arizona's E-Verify mandate achieved its goal of deterring unauthorized immigration and employment, it also generated unintended consequences on the labor market. In addition to constricting employment among unauthorized immigrants, LAWA also reduced employment opportunities among some low-skilled legal workers. Though these negative employment effects are very small in magnitude, they are ostensibly the opposite of hoped-for effects among some supporters of the law. However, the largest group of low-skilled authorized men in Arizona, non-Hispanic whites, earned higher wages on average, as well. Impacts on other, smaller, groups of low-skilled authorized workers remain unknown and are worthy of further study.

Policymakers should weigh this mixed set of impacts when considering E-Verify mandates. Since LAWA, a number of states have instituted mandates of varying degree. As more places institute similar policies, the labor market mechanisms and impacts of E-Verify policy may change. In Arizona, LAWA's impacts appear to have been dominated by a reduction in labor supply, a decline in unauthorized workers who left for or chose other states over Arizona. As more states introduce E-Verify, however, fewer migration alternatives exist and the less likely we are to observe sizeable labor supply reductions. Hypothetically a federal E-Verify mandate, such as those included in previous reform proposals in the U.S. Congress, would clamp down on this mechanism even further. 
The extent to which E-Verify impacts the scale of business, which reinforced downward pressure on employment in Arizona, may depend on the degree of enforcement. This may vary over time, if employers learn enforcement is lax, and may vary across places. States that have implemented mandates vary substantially in the degree of enforcement they have set forth. In addition, current policies contain a variety of loopholes, such as the independent contractor loophole in LAWA, which we found to have significant impacts on labor market adjustments. Thus, it is important to use caution when generalizing impacts of LAWA to broader policy debates.

However, there are lessons to be learned from a single state's experience. While LAWA appears to have achieved its goal of reducing the presence and employment of unauthorized immigrants in the state, no evidence suggests that it improved the likelihood of employment for competing workers. While some legal workers earned relatively higher wages as a result, fewer found employment in the state following LAWA. 


\section{References}

Abadie, Alberto; Diamond, Alexis and Jens Hainmueller (2010). "Synthetic Control Methods for Comparative Case Studies: Estimating the Effect of California’s Tobacco Control Program,” Journal of the American Statistical Association, 105(490): 493-505.

Arizona Attorney General (2010). Website: Arizona Employers Enrolled in E-Verify, http://www.azag.gov/LegalAZWorkersAct/EVerifyList.html, accessed March 2010.

Bansak, Cynthia and Steven Raphael (2001) "Immigration Reform and the Earnings of Latino Workers: Do Employer Sanctions Cause Discrimination?” Industrial \& Labor Relations Review, 54(2): 275-295.

Bohn, Sarah and Magnus Lofstrom (2013). “Employment Effects of State Legislation”, in David Card and Steven Raphael (eds.) Immigration, Poverty, and Socioeconomic Inequality, Russell Sage, pp. 282-314.

Bohn, Sarah, Magnus Lofstrom and Steven Raphael (2014). "Did the 2007 Legal Arizona Workers Act Reduce the State’s Unauthorized Immigrant Population?” Review of Economics and Statistics 96(2): 258-269.

Buchmueller, Thomas C, DiNardo, John and Robert G. Valleta (2009). “The Effect of An Employer Health Insurance Mandate on Health Insurance Coverage and the Demand for Labor: Evidence from Hawaii,” Federal Reserve Bank of San Francisco Working Paper \#2009-08.

Congressional Budget Office (2008). Memo from Director Orzag to Committee on the Judiciary dated April 4, 2008.

De Soto, Hernando (1989). The Other Path. New York: Harper \& Row Publishers

Good, Michael (2013). Do immigrant outflows lead to native inflows? An empirical analysis of the migratory responses to US state immigration legislation. Applied Economics 45:4275-97.

Hoefer, Michael, Nancy Rytina, and Bryan Baker (2010). Estimates of the Unauthorized Immigrant Population Residing in the United States: January 2009. Washington DC, Department of Homeland Security Office of Immigration Statistics.

Lofstrom, Magnus, Laura Hill and Joe Hayes (2013). "Wage and Mobility Effects of Legalization: Evidence from the New Immigrant Survey”, Journal of Regional Science, 2013, 53:1, pp.171-197.

Los Angeles Times (April 19,2010). Arizona has rarely invoked its last tough immigration law, by Nicole Santa Cruz.

National Conference of State Legislatures (2006-2010). 2006-2010 State Legislation Related to Immigratns: Enacted and Vetoed. Washington DC. 
Office of Immigration Statistics (2010). “2009 Yearbook of Immigration Statistics”, Department of Homeland Security.

Passel, Jeffrey, D'Vera Cohn and Ana Gonzalez-Barrera (2013). Population Decline of Unauthorized Immigrants Stalls, May Have Reversed. Washington DC, Pew Hispanic Center.

Passel, Jeffrey and D'Vera Cohn (2009a). A Portrait of Unauthorized Immigrants in the United States. Washington DC, Pew Hispanic Center.

Passel, Jeffrey and D'Vera Cohn (2009b). Mexican Immigrants: How Many Come? How Many leave? Washington DC, Pew Hispanic Center.

Rosenblum, M. (2009). The Basics of E-Verify, the US Employer Verification System.

Washington DC, Migration Policy Institute.

Stark, Oded and Marcin Jakubek (2012). Employer sanctions and the welfare of native workers. Economics Letters 117:533-6.

Westat (2007) Findings of the Web Basic Pilot Evaluation. Rockville, MD.

Westat (2009). Findings of the E-Verify Program Evaluation. Rockville, MD 
Figure 1: Annual Employment Growth in Arizona and Bordering States, 1999-2009

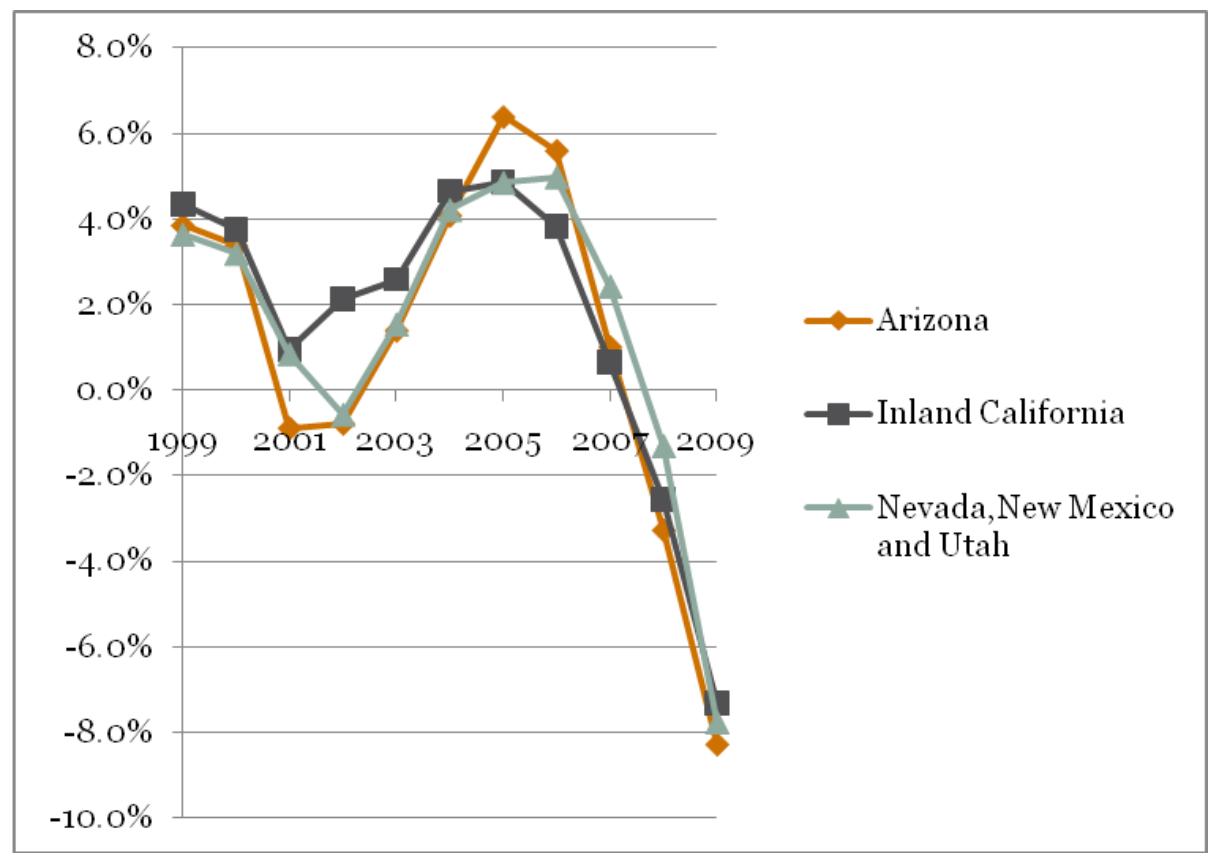

SOURCE: Author’s calculations from the 1998-2009 Quarterly Census of Employment and Wages (QCEW)

Figure 2: Annual Employment Growth in Construction in Arizona and Bordering States, 1999-2009

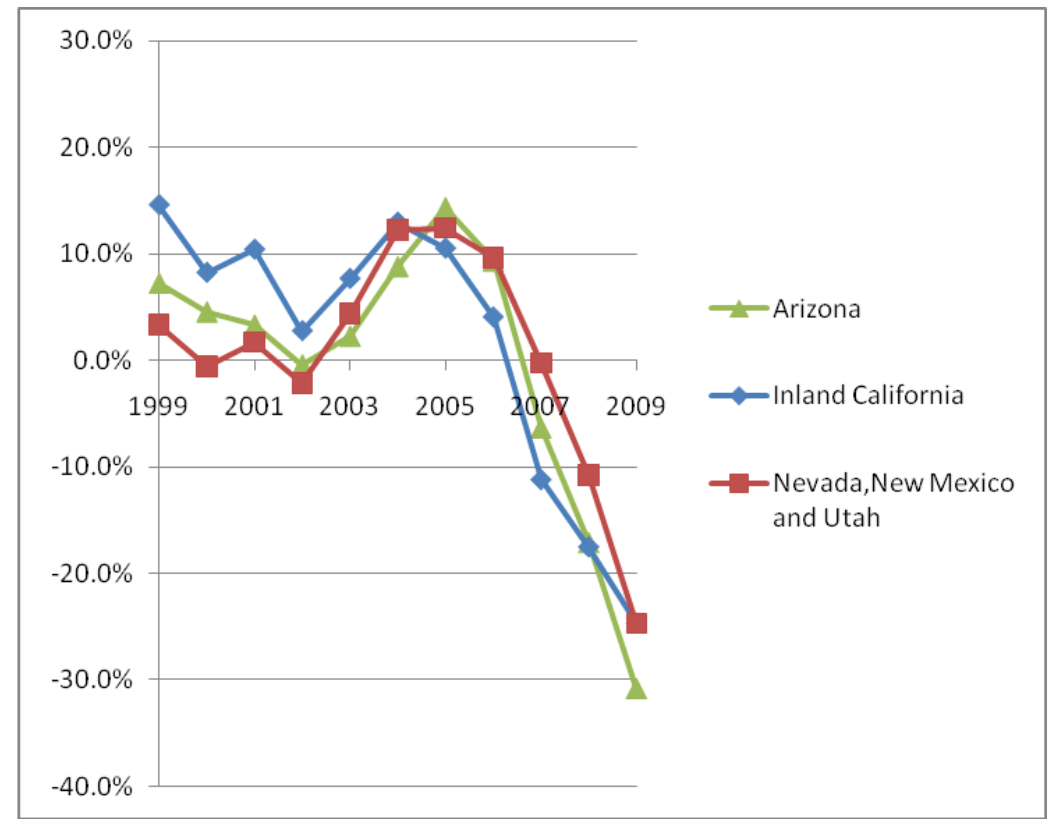

SOURCE: Author’s calculations from the 1998-2009 Quarterly Census of Employment and Wages (QCEW) 
Figure 3.

Employment Rates for Low-Skilled Working-Age Authorized Men in Arizona, 1998-2009

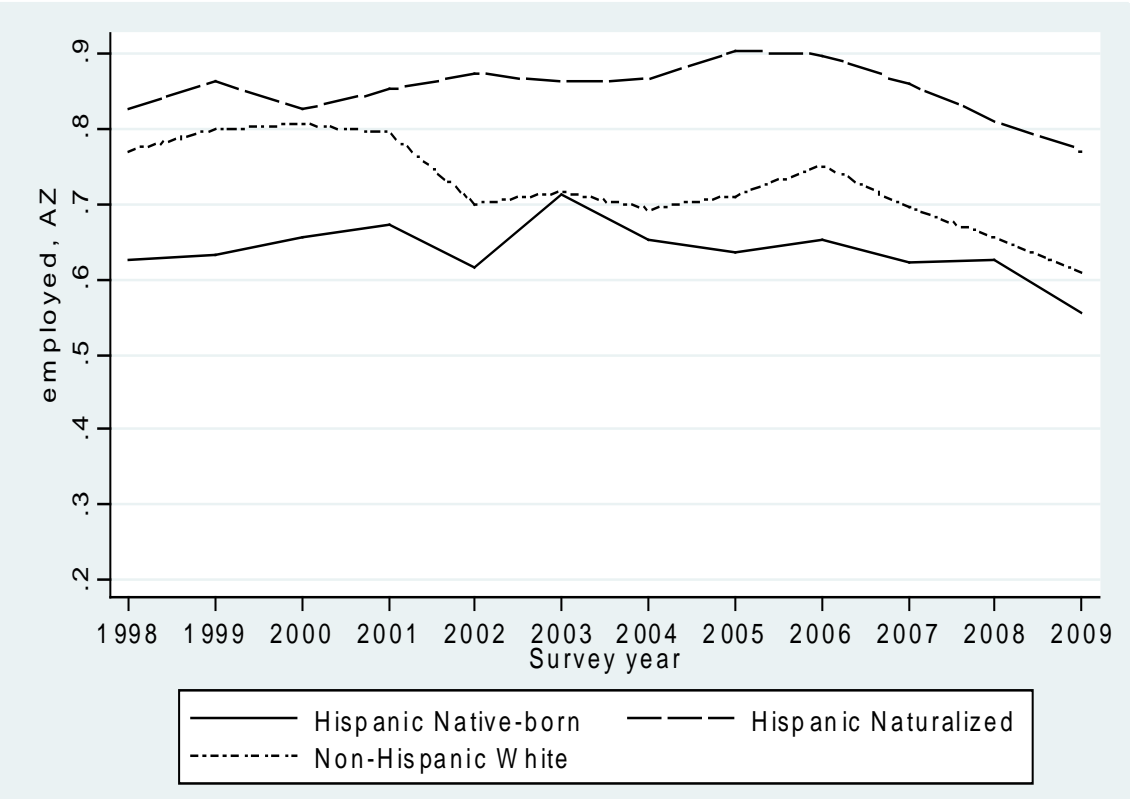

SOURCE: Author’s calculations from the 1998-2009 monthly CPS

\section{Figure 4.}

Employment Rates for White Native-born Working-Age Men with High School or Less, Arizona and Synthetic Arizona, 1998-2009

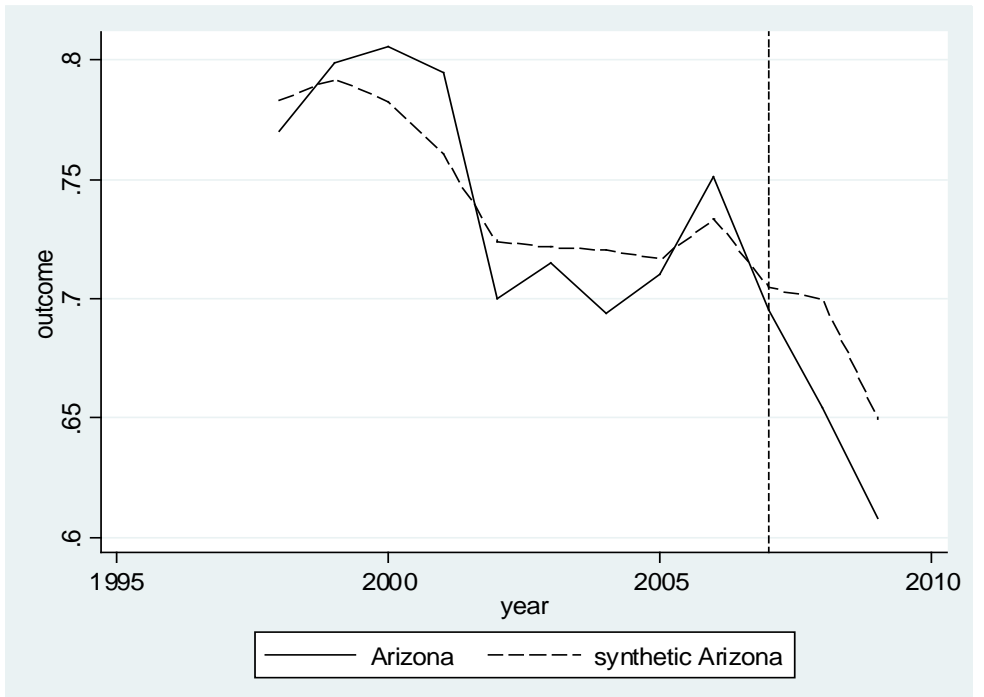

SOURCE: Author's calculations from the 1998-2009 monthly CPS

NOTE: Synthetic Arizona consists of the following states (with weights in parentheses): Alaska (0.32), Illinois (0.054), Indiana (0.527), and Kentucky (0.087). 
Figure 5. Difference in Employment Rates Relative to the Synthetic Control Group, White Native-born Working-Age Men with High School or Less, All States (Arizona Displayed with Thick Black Line)

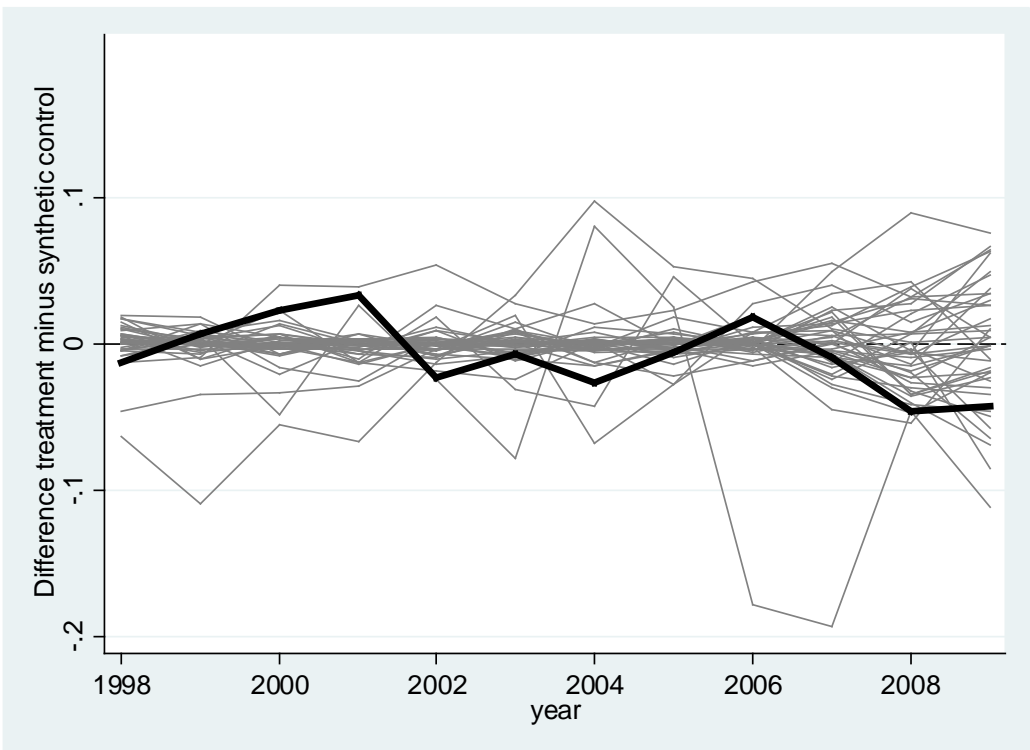

SOURCE: Author's calculations from the 1998-2009 monthly CPS

Figure 6.

Unemployment Rates for White Native-born Working-Age Men with High School or Less, Arizona and Synthetic Arizona, 1998-2009

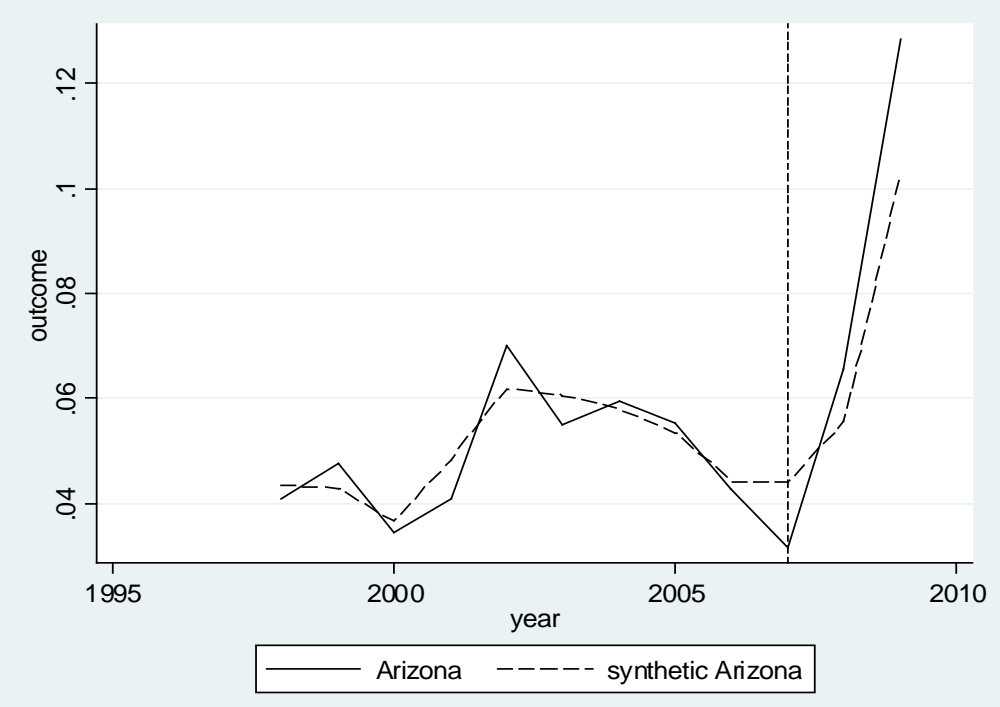

SOURCE: Author's calculations from the 1998-2009 monthly CPS

NOTE: Synthetic Arizona consists of the following states (with weights in parentheses): Idaho (0.362), Iowa (0.385) Massachusetts (0.172), Pennsylvania (0.063), and West Virginia (0.017). 
Figure 7. Difference in Unemployment Rates Relative to the Synthetic Control Group, White Native-born Working-Age Men with High School or Less, All States (Arizona Displayed with Thick Black Line).

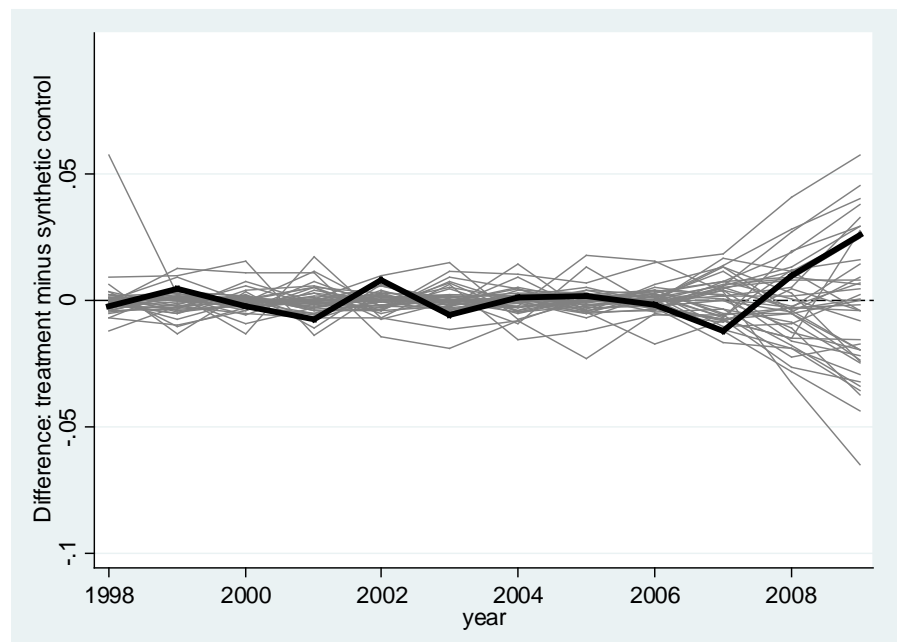

SOURCE: Author’s calculations from the 1998-2009 monthly CPS

Figure 8.

Average Hourly Earnings for White Native-born Working-Age Men with High School or Less, Arizona and Synthetic Arizona, 1998-2009

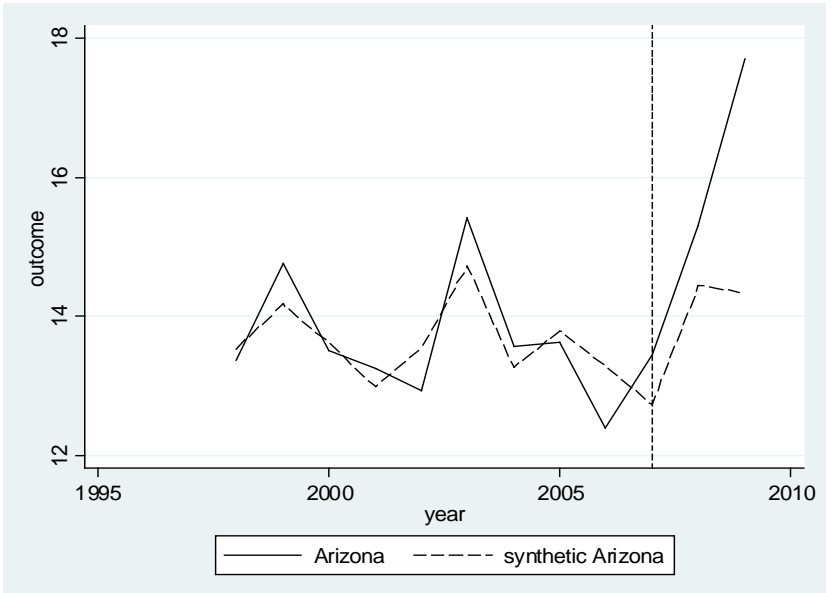

SOURCE: Author's calculations from the 1999-2010 March CPS

Notes: Hourly earnings calculated for all employed persons using data on last year's earnings weeks worked, and hours, in 1999 dollars. The x-axis above shows the reference period, rather than survey year. Synthetic Arizona consists of the following states (with weights in parentheses): Arkansas (0.257), Delaware (0.056), Hawaii (0.077), Missouri (0.237), Oklahoma (0.129), and Oregon (0.244). 
Figure 9.

Difference in Average Hourly Earnings Relative to the Synthetic Control Group, White Native-born Working-Age Men with High School or Less, All States (Arizona Displayed with Thick Black Line).

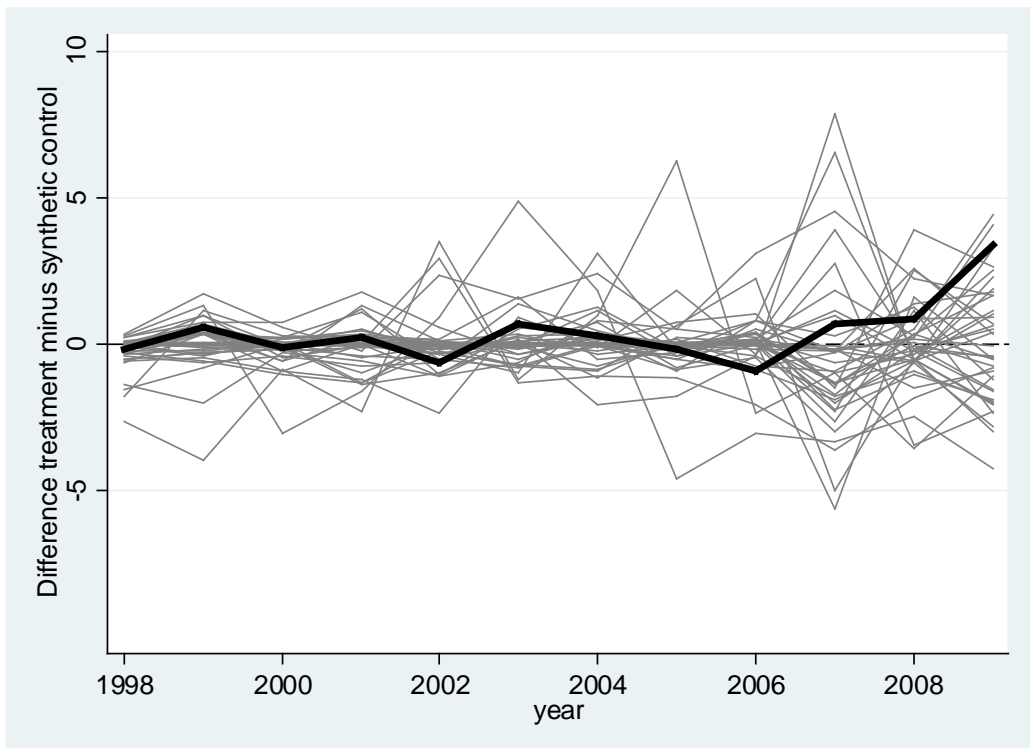

SOURCE: Author's calculations from the 1999-2010 March CPS. 


\section{Table 1.}

Descriptive Statistics, Low-skilled Working-Age Men, 1998-2009

\begin{tabular}{llll|lll} 
& \multicolumn{3}{c}{ Arizona } & \multicolumn{3}{c}{ Donor Pool States } \\
\hline & $\begin{array}{l}\text { White native- } \\
\text { born }\end{array}$ & $\begin{array}{l}\text { Hispanic } \\
\text { native-born }\end{array}$ & $\begin{array}{l}\text { Hispanic } \\
\text { naturalized }\end{array}$ & $\begin{array}{l}\text { White } \\
\text { native-born }\end{array}$ & $\begin{array}{l}\text { Hispanic } \\
\text { native-born }\end{array}$ & $\begin{array}{l}\text { Hispanic } \\
\text { naturalized }\end{array}$ \\
\hline Avg Sample size & 1,475 & 625 & 733 & 3,078 & 354 & 452 \\
Avg Weighted sample size & 355,587 & 151,013 & 179,238 & 531,723 & 72,612 & 97,776 \\
Employment rate & $72 \%$ & $64 \%$ & $85 \%$ & $74 \%$ & $69 \%$ & $86 \%$ \\
Unemployment rate & $6 \%$ & $9 \%$ & $5 \%$ & $5 \%$ & $8 \%$ & $5 \%$ \\
Share not in labor force & $22 \%$ & $27 \%$ & $10 \%$ & $21 \%$ & $23 \%$ & $9 \%$ \\
$\begin{array}{l}\text { Earnings at current job: } \\
\text { weekly (mean) }\end{array}$ & 569.27 & 451.00 & 335.79 & 570.73 & 485.43 & 395.85 \\
weekly (median) & 498.89 & 407.40 & 303.46 & 514.96 & 459.70 & 367.54 \\
Earnings last year: & & & & & & \\
weekly (mean) & 580.75 & 592.38 & 374.66 & 593.91 & 471.25 & 394.76 \\
weekly (median) & 488.73 & 396.22 & 311.95 & 501.31 & 405.49 & 339.37 \\
annual (mean) & $28,206.28$ & $23,634.19$ & $17,800.64$ & $27,981.10$ & $22,028.12$ & $18,347.71$ \\
annual (median) & $23,929.00$ & $18,248.88$ & $15,973.98$ & $24,326.71$ & $19,190.93$ & $16,172.17$ \\
hourly (mean) & 14.10 & 15.38 & 9.47 & 14.72 & 11.82 & 9.85 \\
\hline
\end{tabular}

NOTES: Author's calculations from the 1998-2010 monthly CPS. All but the final five rows utilize 1998-2009 data only. Earnings calculated for employed persons only. Donor pool states include all except those with similar subsequent legislation (Mississippi, Rhode Island, South Carolina, and Utah) and two with missing values for many groups in multiple years (North Dakota and Vermont). 
Table 2.

Estimated Impact of LAWA in Arizona: Employment Outcomes among Low-skilled Working-Age Men

\begin{tabular}{llllll}
\hline & $\begin{array}{l}\text { Pre-average } \\
\text { difference } \\
\text { relative to } \\
\text { synthetic } \\
\text { cohort }\end{array}$ & $\begin{array}{l}\text { Post-average } \\
\text { difference } \\
\text { relative to } \\
\text { synthetic } \\
\text { cohort }\end{array}$ & $\begin{array}{l}\text { Change } \\
\text { (Difference- } \\
\text { in-difference } \\
\text { estimate) }\end{array}$ & $\begin{array}{l}\text { Rank, } \\
\text { difference-in- } \\
\text { difference } \\
\text { estimate }\end{array}$ & $\begin{array}{l}\text { P-value from } \\
\text { one-tailed } \\
\text { test, } \\
\mathrm{P}(|\Delta|<|\Delta \mathrm{AZ}|)\end{array}$ \\
\hline $\begin{array}{l}\text { Employment Rate } \\
\text { White native-born }\end{array}$ & 0.0007 & -0.0436 & -0.0443 & $43 / 45$ & 0.067 \\
Hispanic native-born & -0.0009 & 0.0308 & 0.0316 & $15 / 40$ & 0.650 \\
Hispanic naturalized & -0.0011 & -0.0456 & -0.0446 & $28 / 38$ & 0.244 \\
\hline Unemployment Rate & & & & & \\
White native-born & -0.0004 & 0.0180 & 0.0184 & $37 / 45$ & 0.200 \\
Hispanic native-born & 0.00001 & 0.0445 & 0.0444 & $33 / 40$ & 0.200 \\
Hispanic naturalized & -0.0026 & -0.0037 & -0.0011 & $14 / 25$ & 0.480 \\
\hline Share Not in Labor Force & & & & \\
White native-born & -0.0011 & 0.0172 & 0.0183 & $35 / 45$ & 0.244 \\
Hispanic native-born & 0.0009 & -0.0869 & -0.0879 & $34 / 40$ & 0.175 \\
Hispanic naturalized & 0.0009 & 0.0375 & 0.0365 & $22 / 25$ & 0.160 \\
\hline
\end{tabular}

NOTES: Estimates based on 1998-2009 Current Population Survey basic monthly files. Includes men age 16-60 with a high school education or less. The donor pool size is represented as the denominator of the rank.

Table 3.

Estimated Impact of LAWA in Arizona: Earnings of Low-skilled Working-Age Men who are Non-Hispanic White and Native-born

\begin{tabular}{llllll}
\hline & $\begin{array}{l}\text { Pre-average } \\
\text { difference } \\
\text { relative to } \\
\text { synthetic } \\
\text { cohort }\end{array}$ & $\begin{array}{l}\text { Post-average } \\
\text { difference } \\
\text { relative to } \\
\text { synthetic } \\
\text { cohort }\end{array}$ & $\begin{array}{l}\text { Change } \\
\text { (Difference- } \\
\text { in-difference } \\
\text { estimate) }\end{array}$ & $\begin{array}{l}\text { Rank, } \\
\text { difference } \\
\text {-in- } \\
\text { difference } \\
\text { estimate }\end{array}$ & $\begin{array}{l}\text { P-value from } \\
\text { one-tailed } \\
\text { test, }\end{array}$ \\
\begin{tabular}{lllll}
$\mathrm{P}(|\Delta|<|\Delta \mathrm{AZ}|)$ \\
\hline Earnings at Current Job
\end{tabular} & & & & & \\
Weekly earnings (mean) & -5.26 & 148.94 & 154.20 & $42 / 44$ & 0.068 \\
Weekly earnings (median) & -5.16 & 111.17 & 116.34 & $41 / 44$ & 0.091 \\
\hline & & & & & \\
Earnings over Full Year & & & & & \\
Weekly earnings (mean) & -2.45 & 122.27 & 124.73 & $45 / 45$ & 0.022 \\
Weekly earnings (median) & -2.32 & 21.65 & 23.97 & $38 / 45$ & 0.178 \\
Annual earnings (mean) & -16.16 & 5443.40 & 5459.56 & $43 / 45$ & 0.067 \\
Annual earnings (median) & 50.54 & 1420.18 & 1369.64 & $39 / 45$ & 0.156 \\
Hourly wage (mean) & -0.01 & 2.11 & 2.12 & $42 / 45$ & 0.089 \\
\hline
\end{tabular}

NOTES: Estimates based on 1998-20010 Annual Social and Economic Supplement to the Current Population Survey. Current or "usual” earnings at current job outcomes utilize 1998-2009 years of the CPS. Earnings in the full year prior to the survey use 1999-2010 CPS data and align reference period with pre- and post-LAWA periods appropriately. Only non-missing and non-zero observations are used to calculate state-wide outcomes. 